\title{
OSU CASTE SYSTEM AND HUMAN RIGHTS IN IGBOLAND, 1900-2017
}

O. T. ABIA, NNEKA SOPHIE AMALU AND CHRISANTUS K. ARICHE

(Received 5 February 2021, Revision Accepted 12 April 2021)

\begin{abstract}
Discrimination and caste systems are rife in every society. In Igboland, the Osu caste system is a form of discriminatory practise where the Igbo society is divided into the Diala and Osu. The problem is that this divide comes with human rights restrictions and violations on the part of the Osu which go unreported and unaddressed at both national and international discourses. Literature on the Osu caste system has majorly focused on various aspects with little attention paid to the human rights dimension of the Osu caste system. Thus, this paper seeks to examine the Osu caste system within the human rights prism. The natural rights theory of John Locke is used as framework of analysis. Findings reveal that the people call Osu face all forms of discrimination and violations of their fundamental human rights. Education and psychological counselling, among other factors were recommended in order to eliminate the caste system. Also, religious bodies as well as the social media can play a vital role in the campaign against the Osu caste system.
\end{abstract}

KEYWORDS: Osu caste system, Diala, Human rights, Discrimination, UDHR

\section{INTRODUCTION}

In human history, every age and people have their own problems, either natural (earthquakes, flood, etcetera.) or man-made. In every society, social stratification, discrimination, prejudice and injustices do exist and may differ from one society to the other. It can take several forms, be it economic, social, religious and even political. It exists among individuals, ethnic groups and nations. While one group claims superiority over another, some nations claim superiority over another and it is called different names by different cultures in different societies. The caste system is one of such problem made by man and is the second system of social stratification in which status is determined by birth, marriage is restricted to member of one's own caste and is lifelong (Henslin, 2005, Ember et al., 2005).

Amongst the Igbo of South-east zone of Nigeria (Amalu, 2018, p.107), there is the caste system the Osu caste system. It is perhaps among the world's longest surviving status discrimination as that of the Indian caste system; and it is believed to be as old as Igboland itself, or as "old as the killing of twin babies, the killing of innocent children for developing first the upper incisor (teeth) the offering of human sacrifices, the

O. T. Abia, Department of History and International Studies University of Calabar, Calabar, Nigeria Nneka Sophie Amalu, Department of History and International Studies University of Calabar, Calabar, Nigeria.

Chrisantus K. Ariche, Department of Philosophy University of Calabar, Calabar, Nigeria.

(C) 2021 Bachudo Science Co. Ltd. This work is licensed under Creative Commons Attribution 4.0 International license. 
problematic ideas of reincarnation and others which were practiced in the ancient Igbo nation and other nations in Nigeria and Africa at large" (Onwubuariri, 2016, p.55). The system is a tradition that has been handed over from one generation to the other and has not been influenced to a great extent by westernization, Christianity, civilization, advancement in science, globalisation or even democracy and the human rights culture; the people continue to give strict observance or face dire consequences. Mgbada (2016, p.351) argues that "of all the customs of Igboland and perhaps Africa at large that Europeans considered repugnant to natural justice, equity and good conscience such as twin killing and extra judicial killing of thieves, the Osu caste system has been the most obstinate in resisting extermination". While claiming that the system appears to be the most fundamental and unshakable, he further states that "it is fundamental because it is almost aboriginally attached to the traditional system of peoplemaking the necessary distinction between those "free" and "properly" born with legitimacy into the society and those regarded as "illegitimate" by virtue and circumstance of their birth or arrival in the society or, indeed, ultimately by circumstance of their being dedicated to one god or the other"(Mgbada, 2016, p.55).

The Osu caste system has become an iota of disunity, humiliation, infringement, isolation, in the places where they practiced. The Osu experience all forms of dehumanization and discrimination, social exclusion and human rights abuses throughout their lifetime as a result of their status. Human right are legal entitlements which every citizen must enjoy without fear of the government or fellow citizens (Amalu, 2019, p. 135). Any culture or society (tradition and custom) that abridges the people's freedom of association violates their human and civil rights, which clearly is a violation of the Universal Declaration of Human Rights by the United Nations General Assembly on 10 December, 1948, which stands as the cornerstone document for human rights all over the world. Thus, it is against this backdrop that this paper seeks to examine the human rights dimension of the Osu caste system in Igboland.

This work is hinged on the John Locke's (16321704) theory of Natural Rights which states that "men being by nature all free, equal and independent, no one can be put out of this estate and subjected to the political power of another without his own consent" (William, 2002, p.28). This theory attests to the fact that human beings are born with some natural rights which they strive to protect and preserve; and cannot be taken away from them. Hence, in the context of this work, everyone whether Osu or Diala in Igboland is entitled to basic natural rights; at least, right to life, liberty and property amongst others. Thus, the consistent discrimination and denial of certain rights of people branded Osu is an aberration and inimical to the natural rights theory as posited by Locke. Thus, according to Omorogbe (1991, p.97) "when we talk of the equality of all men, we mean ontological equality. Simply put, what makes a being 'human' is the same in all men and that all men are equally human, no man is more of a human being than another man.

\section{The Osu Caste System: A Brief Exposition}

Like most social systems, the origin of the Osu caste system is very vague, unclear, and there is no consensus as to when the system was established, Amadife (1988) traces the origin of the Osu caste system to the era when the gods were believed to demand for human sacrifice during festivals, so as to cleanse the land of abomination; then the people would contribute to the general purse for a purchase of a slave or for kidnapping one.

Another school holds that the Osu caste system originated from the Nri Kingdom. It is believed that in the olden days, Nri people possessed some hereditary powers and rites to proclaim cleansing to any kingdom where abominations were done in the past consequently, any community or kingdom that refuted or regretted the cleansing by the Nri spiritualist or any village that is unable to meet up with requirements needed for the cleansing was viewed as impure; and any community that was termed impure was referred to as Osu or untouchable.

However, it is the position of the paper that the Osu caste was non-existent before in Igboland at the beginning. Those who later became Osu were first free born or sons and daughters of the soil. There are various ways in which the Osu status can be acquired. It can be acquired through birth by Osu parents, intermarriage and commensality. Historically, a person became Osuif she was purchased and dedicated to the god to atone for a crime the purchaser had sought sacred help in difficult times, or to secure asylum (such as women who refused the killing of their twin babies, or babies whose upper teeth came out first). Some of these modes of acquiring the Osu status is now obsolete as Western influence has affected this practice; in 
modern-day, inheritance and marriage are the strongest factors (Dike, 2002). One thing certain is that, in whichever manner the status of Osu is acquired, it is permanent.

To identify an Osu is not difficult. Some parts of his body, like an ear or a finger is also cut to identify him. Apart from the marks, "one can also identify an Osu by their inherent devastating body odour. It is said that Osu has a very bad body odour that no matter how they try to remove it with perfume it does not go" (Onwubuariri, 2016, p.65). Another way of identifying an Osu is by the places they live. They are found in outskirts and fringes of the community. In spite of their status, the Osu have certain responsibilities outside their immediate communities (among fellow Osu).The Osu is like priest of the cult and in some cases, subjects of the chief priests. They keep vigil in the village when the house slaves (Ohu or Oru) and their master must have gone to farm as well as the protection of couples still with little children that are prone to kidnap. During inter-tribal wars, the Osu were given charm pots to carry as they approached the battle zone. They also served as frontiers. An Osu is the living symbol of the invisible spirit when he is carrying the emblem (of the spirit or a god). The emblem carrier is seen as the most important person on such occasions, this is because, in the very blood of the Osu runs the potency of the spirit, hence, they are feared. Hence, it is evident that Osu occupy crucial positions and play important roles in Igboland cutting across the socio-economic and cultural spheres.

\section{Osu Caste System and Human Rights}

There is no better way of articulating the interrelatedness of human rights and the Osu caste system than the human rights violations consequent upon the discrimination of the Osu. The Osu people are seen to be stigmatized and highly dreaded people. The system touches on the person's dignity and self- worth. He permanently has a scar and no matter his status in the society, it cannot be erased. The Osu caste system infringes on fundamental human rights in the following ways:

\section{Freedom from Discrimination}

"The crux of the Osu caste system is the discrimination that comes with it. This people are discriminated in all ramifications....Mezie-Okoye and Asike (2019, p.91) claimed the Osu right to freedom from discrimination is been infringed upon by the Diala or those who called themselves free borns. Freedom from discrimination is a fundamental right that every citizen or individual should enjoy irrespective of tribe, race, colour, sex, and so on. That is why the law has expressed in Article 7 of the Universal Declaration on Human Rights 1948, that: "All are equal before the law and are entitled without any discrimination to equal protection of the law." All are entitled to equal protection against any discrimination in violation of this Declaration and against any incitement to such discrimination. The Osu discrimination cuts across the social, cultural, economic and political spheres. The Osu caste system is a degrading and dehumanizing system that discriminates one's fellow human being. It is a serious crime and anyone who commits such crime should be punished. Contrary to these provisions of the law as to the right of individuals in Nigeria, the Osu caste system has provided a fundamental breach of individual right to freedom from discrimination in Igboland.

\section{Right to Life, Liberty and Security of Person}

The Osu caste system infringes on the right to life, personal liberty and security. According to Article 3 of Universal Declaration of Human Rights (1948):"Everyone has the right to life, liberty and security of person". Life is the most precious gift on earth and, therefore, it is appropriate that it is given the first place. Adversely, the Osu are deprived of these rights. "The Osu are sentenced to death to appease the gods against further misfortune in the community. He can even be sacrificed to a deity without anybody asking questions about it" (Personal Interview). Nwagbara et al (2011, p.141) state that the breach of life, liberty and security is associated with Osu caste system, although, liberty amongst the Igbo is an inalienable birth right, which is not subject to negotiations and compromise. In essence, to foist the status of Osu on anyone, no matter the circumstance, contradicts the inalienable birth right of any Igbo child which is grounded on liberty." This ironically opposes the traditional and unrecorded constitution of Igbo which, basically emphasizes the spirit of liberty. Liberty connotes in practice an amalgam of free enterprise, freedom to engage in any activity that avails other members of the community. Igwe and Akolokwu (2014, p.282), rightly noted that "liberty, essentially, is freedom but an Osu is not free and is always in chains. His pains are not shared by all as he cannot access the warmth of his neighbours. The chains he bears are heavier than physical chains. Physical chains are for a time, but an Osu chains 
are engraved permanently on his sensibilities, his honour, worth and personality".

\section{Right from Torture, Inhumane Treatment and Punishment}

The Osu caste system violates the right from torture or cruel, inhumane or degrading treatment and punishment. The UDHR article 5 declares that "No one shall be subjected to torture or to cruel, inhuman or degrading treatment or punishment." They constantly face torture, degradation and inhuman treatments. The system in its entirety is dehumanizing and degrading. While consecrating an Osu, his hands and feet are tied like an animal, his head is scrapped and half of his body painted with white chalk. He is left for some couple of days after one of his ears or finger is cut. This cut gives him a permanent mark. Sometimes, the Osu is to be a bearer of the sins of others or community. Hence, he will be dragged by the rope round the village with people hitting him on the head till he is dead and the corpse thrown into the evil forest. Sometimes, he could be half buried till he dies or be burnt on the tree or soldier ants will sting him on the tree till he dies (Lemchi, 2011, p.33).

\section{Right to Equality}

The Right to Equality of the Osu is not guaranteed. Article 1, of UDHR 1948 states that, "All human beings are born free and equal in dignity and rights. They are endowed with reason and conscience and should act towards one another in a spirit of brotherhood." Also, article 7 of UDHR (1948), also reads "All are equal before the law and are entitled without any discrimination to equal protection against any discrimination in violation of this Declaration and against any incitement to such discrimination."

The Osu is usually seen as a lesser or unequal or inferior being. They are seen as lesser beings and inferior while the Diala are superior and regarded as people with ancestral home." They constantly try to dominate them. The situation in Awka-Etiti in Anambra State is one where the Osu and the Diala (like in any other communities) live in different parts of the community. Any person from the Osu area is automatically a recluse, inspite of wealth, academic qualification, etc. In this way, the question of an Osu marrying whomsoever he or she wants is out of the place. They are not allowed to marry Diala who is a superior being or the Diala to marry Osu an inferior person. To the Diala, the Osu blood is impure and weaker, while theirs is purer and stronger. All these "are directly subversives of the principle of equality which is surely to deprive the citizen of liberty (Lemchi, 2011, p. 57).

\section{Right to Marriage and Family Life}

The right to marriage and family is violated. Article 16 (1) of the UDHR (1948) declares that, "Men and Women of full age, without any limitation due to race, nationality, without any limitation due to race, nationality or religion, have the right to marry and to found a family. They are entitled to equal rights as to marriage, during marriage and at its dissolution." In the case of Osu, they do not have the right to marry or have a family with the a Diala. It is an atrocity for the Diala to marry an Osu. In Isiala Mbano as well as virtually all Igbo communities, the Osu and Diala do not inter-marry. Lemchi (2011, p.56) has noted that the reasons why the Diala do not marry Osu or Diala parents do not allow their children to marry Osu is because they see the Diala as having a purer and stronger blood and the Osu an impure and weaker blood of which if the two blood meets together, it will invoke a punishment on both the people and the entire community. It is known by man that marriage and procreation are the basic natural rights of man and fundamental to every existence and survival of the race. To deny this fundamental freedom on the basis of weaker and stronger blood is an infringement on his right to marriage and family. A popular case is recounted in a personal interview in Imo State, where one Mr. Vincent de Paul Ohiri wedded a lady known as Ann Nwokeocha at St. Kevin's Catholic Church, Ogbaku, in Mbaitoli LGA, July 30, 2011. The Osu man saw this union as victory, but for the bride's family it was an atrocity. The bride to be who was a Dialawas ostracized from her family for consenting to marry a man, who the family described as Osu. This event showed that the rights to marry anyone is yet to be granted to the Osu as other restrictions in contemporary times are minimal while others have been discarded.

\section{Right to Fair Hearing/Presumed Innocent Until Proven Guilty}

Article 10 of the UDHR (1984) provides that "everyone is entitled in full equality to a fair and public hearing by an independent and impartial tribunal, in the determination of his rights and obligations and of any criminal charge against him." In certain cases, in courts outside his community, an Osu will have full right to fair hearing or presumed innocent until proven guilty, but if it is the native courts which are made up of mainly the Diala and the Osu a minority, he may 
not have such rights. The Osu in such instance cannot get justice from the same persons who sees him, as outcast. Justice involves "lawfulness and fairness, equitable distribution of goods and services" (Ezedike \& Ariche, 2019, p.133). Hence, for the Diala, an Osu is an inferior being and "it is an ugly event to adjudicate against any of their members who is always considered more human and ancestor incarnated than the Osu when there is a dispute between the two" (Lemchi, 2011, p.120).

When this becomes the case, justice is denied to the Osu even when every element is pointing towards their liberty. Oftentimes, when a case between an Osu and Diala is presented, the Osu fate is already pre-determined. In such situation, his right to presumed innocent until proven guilty is violated. Article 11 of the UDHR that: "Every person who is charged with a criminal offence shall be presumed to be innocent until proven guilty." Igwe and Akolokwu (2014, p.283) stated that the Osu's fate as "pre-determined condemnation". The Osu may decide to take it to superior courts, if he has the financial means, however, if he wins, the hostility that awaits him back home is better imagined.

\section{Right to of Thought, Conscience and Religion} In Article 18 of the UDHR (1948) "Everyone has the right to freedom of thought, conscience and religion; this right includes freedom to change his religion or belief, and freedom, either alone or in community with others and in public or private, to manifest his religion or belief in teaching, practice, worship and observance."

Nevertheless, the provisions of the UDHR (1948) raises some concerns as it may seem that they promote the beliefs, thoughts and conscience that forms the framework or justifies the continuous practice of the Osu caste institution. Igwe and Akolokwu (2014, p. 283) asserted that "in the face of it after all, since it is ancestral in nature, it compels obedience from the present practitioners who may claim freedom of belief or religion." This contention is well brought out by article 9(2) which subjects the exercise of this right to such limitations as are prescribed by law and are necessary in a democratic society in the interest of public safety, for the protection of public order, health or morals, or for the protection of the rights and freedom of others. The provision reveals that appropriate exercise of the freedom must be in the perspective of other persona rights in the same directions, and above all, on the whole intendment of the law. Freedom appropriately so called must be freedom exercised in limitation of other freedoms in an impartial unbiased way.

\section{Freedom of Worship}

All human beings have the right to freedom of worship, but for the Osu, this right is denied. Freedom of worship is a constitutional right to Nigerian citizens. Just like in other nations of the world, when people are denied this freedom, it is a breach to their fundamental rights. All citizens of Nigeria are entitled to freedom of worship in an environment that encourages self-expression. However, the Osu people are not availed such freedom for the most part of lgbo communities. Cases have been recorded where in the glower of all worshippers in church; offerings of the Osu are kept separately from that of the Diala. "This is an affliction directed at the core of spirituality of the Osu. Indeed, there is greater fulfilment in spirituality if a worshipper serves his God in the serenity of self-expression devoid of any hindrance"(Igwe and Akolokwu, 2014, p. 284). Sometimes, they Osu seat in different places in church.

\section{Right to Acquire and Own Property}

The Osu's right to acquire and own property anywhere in Nigeria is guaranteed by the provisions of Article 17 of UDHR (1948) which declares that: "everyone has the right to own property alone as well as in association with others. And that, No one shall be arbitrarily deprived of his property." The Osu is denied the right to acquire and own immovable property in his community. The Osu has no right to own land according to tradition. Land belongs to the community which excludes the Osu. Land is shared only to the Diala segment. It is a punishable abomination for a Diala to sell land to an Osu as the former risks bearing the Osu mark. Furthermore, the Osu people were never allowed to build houses near a Diala own because an abomination will be committed if rain falls and washes mud from the Osu houses to free borns. Thus, this is the justification for why most Osu live near shrines and confined places, usually outskirts and fringes of the community. It is also believed that as they live at the edges, any impending calamity that might befall the community will be absorbed by them. 
Right to Participate in Political and Cultural Activities

Article 21 (1) of UDHR (1948) that: "Everyone has the right to take part in the government of his country, directly or through freely chosen representatives." Voting is a right and an obligation of every citizen. It is a key piece of our participation in society. The Constitution of Nigeria ensures that all Nigerians over 18 years of age have the right to participate in elections by method of suffrage.

No matter how wise an Osu is, his wisdom rests with them. To the Diala, he is a nonentity and an insignificant person. $\mathrm{He}$ is excluded from participating in political and cultural activities. For instance, an interviewee stated that "This discrimination was meted to a councillor aspirant at Imo state who was denied the opportunity to contest in an elective position, just because he was an Osu, which on the other hand infringes on his political right "...to be voted for" in an election." The Osu caste system of Igboland has over the years discriminated against the Osu population in striving towards political authority. In some communities even if the Osu is better qualified than the Diala, he will not be given that political support." The Diala could even vote against anyone who attempts abolishing the system.

Article 27(1) of the UDHR states that "Everyone has the right freely to participate in the cultural life of the community......" The Osu is restricted in certain cultural activities. For an Osu to wear mask is to assume power, which the Diala defies. The masked spirits are considered as an appearance of the ancestors who use this means to teach, to educate, and to inculcate discipline, to settle disputes and maintain orderliness in the community or society. The Osu cannot dance where the Diala dances so as not to touch and contaminate the Diala. These functions are regarded very highly and superior, hence, an Osu cannot perform such things. In Igboland, the kolanuts is sacred and has traditional and ritualistic functions. Thus, Osu people are not allowed to break kolanuts in public. The Ozo institution is one of the most important Igbo social institutions of all times. No matter how wealthy an Osu is, he cannot take a title. Because the ozo title holders constitute, for the most part, the narrow aristocracy of intellect, wealth and political power in their societies. It becomes an abomination for an Osu to aspire to it. In the same vein, offering sacrifices as well as divination and oracular functions are prohibited. For an Osu to offer a sacrifice to a deity on behalf of the people is an abomination and a sin against the laws of the land. It is assumed that even if he is allowed to perform such functions, the deities will refuse the sacrifice because he is not qualified to do so. The Osu duties are restricted to cleaning, sweeping, and fetching firewood for the shrine as well as running errands. Also, after a sacrificial process, the animal, either goat or sheep or cow, is usually shared among the members of the community. Most often, the Osu does not take part in this sharing. Even if he is allowed, he will choose last and oftentimes the remnants of the meat eaten by the Diala.

\section{Right to Peaceful Assembly and Association}

The Osu's rights to peaceful assembly and association is denied. The Osu are not allowed to fetch water from the same stream, buy or sell in the same market or sit in council meeting with the Diala or participate in any group functions.

According to the UDHR (1948) in Article 20 (1), "Everyone has right to peaceful assembly and association," while Number (2) states that "No one may be compelled to belong to an association." The application of this law is not visible to the caste system of Osu. It does not coerce the Diala to accept the Osu in dealings. Dike (2007,p. 48) argued that "any culture (tradition and custom) that breaches a people's freedom of association violates their human and civil rights. The Osu cannot aspire to such traditional offices because he lacks the obligatory prerequisite.

\section{- $\quad$ Freedom of expression}

The freedom of expression and speech is a pivotal right in international law, which also finds its way in the national laws of Nigeria society. By the provisions of Article 19 of Universal Declaration of Human Rights: "Everyone has the right to freedom of opinion and expression; this right includes freedom to hold opinions without interference and to seek, receive and impart information and ideas through any media and regardless of frontier."

Under this status, the Osu lack of ability to enjoy the freedom of expression is glaring, though with intricate implications. "In a typical village setting in Igbo land, if an Osu for instance is refused access to marry a girl, how does his right to expression avail him? Will there be a majestic order to compelling the family in question to hand over the girl to him?" (Igwe and Akolokwu, 2014, p.284). These are questions that reveal the height of discrimination meted on the Osu, as they are not allowed to air out their opinion even 
during public traditional meetings. The Osu right to expression and free opinion in relevant occasion where it may be required is denied. But recently, this limitation has reduced drastically as a result of modernization and technological advancement.

\section{Abolition attempts of the Osu caste system}

Before 1960 several attempts were made to abolish the Osu caste system. It could be recalled that Balonowu's Report on bride price reignited the desire to abolish forms of slavery like the Osu caste system after several attempts, some years ago by G. T. Basden. "After the submission of the report, the then minister of Social Welfare immediately swung into action as he moved a motion in the House of Assembly envisaging what a bill for a law for the abolition of the Osu system and to prescribe punishment both for the practice of Osu system and for the enforcement of any disabilities arising from it been passed into law (National Archives Enugu, 1935).

Then, the late Premier of Nigeria Dr. Nnamdi Azikiwe fought vehemently against the Osu caste system, as he told members of the defunct Eastern House of Assembly on March, 201956 that: "it is devilish and most uncharitable to brand any human being with a label of inferiority, due to the accidents of history" (Eastern Regional Assembly, 1956).Another abolition attempt was made during the late Dr. Sam Mbakwe's Nigeria Peoples Party's (NPP) civilian regime in 1979 Imo State, yet it failed. "Nevertheless, in 1956, the Osu abolition Law legally abolished the Osu caste system, work and descent-based discrimination. Although the Osu system was legally abolished, the Osu were and are still subjected to social exclusion, human rights abuses, mistreatment, segregation and discrimination in marriage, employment and political appointments (National Archives Enugu, 1939).

Some communities in Igboland have successfully abolished the caste system and fully integrated the Osu people into the larger community, while others continue to practice it. This is very true as Mgbada (2016, p.51) asserts that "it appears to have become the norm to be judicially noticed even in courts of law, for there is no level of consciousness and radical approach that has not been tried to eradicate the social dichotomy to no avail. In maximum secrecy every Igbo clan maintains a clear distinction between the freeborn and the Diala".
However, there are some schools of thought who assume abolishing the system may have some serious social irregularities and consequences. Some believe that to talk about doing away with it equates taboo (National Archives Enugu, 1935). Lemchi (2011, p.47) captures it thus:

...the breaking up of the Osu system, the long standing ancient Igbo social structure, may lead to some disruption of social life, resulting in absence of cohesion and vast abnormalities in individual behaviour unless some other social structure more suited to the times and the genius of the people takes its place. Some have argued that if the Osu caste system is abolished, a vacuum would be created and if there is nothing to fill the vacuum, the vacuum would fill itself up in a way we may not like.

The possibilities here are that abolishing the system may disrupt the social life and even create a vacuum of which may be filled with something more disastrous such as conflicts, wars and even epidemics and plagues.

\section{CONCLUSION}

The Osu caste system in all ramifications is an abuse and violation of human rights, a clear contradiction to the Universal Declaration of Human Rights, and all other human rights instruments Nigeria is a signatory to. The Osu had no rights to: life, liberty security, peaceful assembly and association, participate in cultural life of the community, political participation, own property, express freely his opinion, right to fair hearing in native courts amongst other rights. These rights were continually infringed upon as they wallowed in such derogatory and dehumanizing practice. These actions made them feel inferior, rejected and unwanted. As the gross violations against the Osu by the Diala continued for such a long time,, the period between 1900 and 2017 was characterised by the Osu struggle to enjoy certain fundamental rights and make themselves significant and relevant in their communities and state in general.

\section{Personal Interviews}

Personal interview 1, Umuode, Enugu State, Telephone Interview, May 15, 2019

Personal Interview 2, Mbatoli, Imo State, Face Interview, June 6, 2019

Personal interview 3, Awka Etiti, Anambra State, Telephone Interview, July, 292019 


\section{REFERENCES}

Amadife, C., 1988. March 23. The Culture That Must Die' Sunday Times. 12(34):3.

Amalu, N. S., 2019. The role of national human rights commission (NHRC) in post conflict situation in Nigeria. International Journal of Art and Humanities (IJAH), 8 (1): 28: 132-142.

Amalu, N. S., 2018. Indigenous symbols and their communicative implications for conflict management and peace building amongst the Igbo, Nigeria 1900-2016. International Journal of Integrative Humanism. Ghana. 8(1): 107-116.

Ezedike, E., and Ariche, C., 2019. Ethical issues in traditional herbal medical practice in Nigeria. International Journal of Humanities and Innovation (IJH) 2(4):129-135.

Dike, V., 2002. The osu caste system in Igboland discrimination based on descent. 61st Session of the Committee on Elimination of Racial Discrimination (CERD) held in London from 8-9 ${ }^{\text {th }}$ August 2002, 22p.

Dike, V., 2007. The Osu caste discrimination in Igboland: Impact on Igbo culture and civilization. iUniverse Publishers, 150pp.

Ember C., Ember M. and Peregrine P., 2005. Anthropology. Eleventh Edition. Pearson Prentice Hall, 2649pp.

Henslin, J., 2005. Sociology: A Down to earth approach. Pearson Publisher, Boston,639pp.

Igwe, O. I., and Akolokwu, G. O., 2014. The Scar that Has Resisted Erasal: The Discrimination of Osu of Igboland, Nigeria-Assessing the Human Rights Implications. American International Journal of Contemporary Research, 4(1):277-285.
Lemchi, B. D., 2011. Osuna Ume: The Osu untouchable. Milestone Publishers, Owerri, 160pp.

Mgbada, C. O., 2016. Osu Caste System and the Problem of Slave Integration in Igboland: The Abakiliki Experience, pp 351-370. In: D. Imbua, C. Ogbogbo, S. Effah, and Y. Ochefu (Editors) Okon Uya @70: Issues in Historiography, Nation-Building and the African Diaspora. 585p. Aboki Publishers, Markurdi.

Mezie-Okoye, C. and Asike J., 2019. Osu caste system in Igbo society, Nigeria: A sociological evaluation. International Journal of Innovative Research and Advanced Studies (IJIRAS), 6(3):89-93.

National Archives Enugu (NAE) 'Intelligent Report on Osu Group, Onitsha Province, 22 February, 1935, File OR-55/ONDIST12/1/523.

Nwagbara, E. Chukwu, C. Okechukwu, A., and Scent, G., 2011 The sociological and human rights implications of ostracism: The case of OsuCcste in the Igbo ethnic group of Nigeria. African Journal of Social Sciences, 1(2):140-151

Omorogbe J., 1991. A simplified history of ancient Philosophy: Ancient and medieval Philosophy. Joja Educational Research and Publishers, Lagos, 167pp.

Onwubuariri, F., 2016. "Appraising the Osu caste system in Igboland within the context of complementary reflection" IGWEBUIKE: An African Journal of Arts and Humanities, 2 (4):54-93.

Universal Declaration of Human Rights (UDHR), 1948.

William L., 2002. The Voyage of Discovery: A Historical Introduction of Philosophy. Wadworth-Thomson learning, Belmont, 592p. 